\title{
传感器电解质 $\mathrm{CaZr}_{1-x} \mathrm{Mg}_{x} \mathrm{O}_{3-\alpha}$ 的导电性能
}

\author{
包金小*，王威威，郭文荣 \\ 内蒙古科技大学材料与冶金学院, 包头 014010 \\ * 联系人, E-mail: baojinxiao2004@yahoo.co.jp
}

2015-08-31 收稿, 2015-09-30 修回, 2015-10-23 接受, 2015-12-01 网络版发表

国家自然科学基金(51464038)、内蒙古自然科学基金(2014BS0507)和内蒙古科技大学卯孚化期项目(2014CY012/2012NCL023)资助

\begin{abstract}
摘要采用固相反应法在 $1673 \mathrm{~K}$ 合成了 $\mathrm{CaZr}_{1-x} \mathrm{Mg}_{x} \mathrm{O}_{3-\alpha}(x=0,0.005,0.01,0.02)$ 陶瓷粉体, 在空气中 $1873 \mathrm{~K}$ 下对材 料进行二次烧结 $10 \mathrm{~h} . \mathrm{X}$ 射线衍射物相分析结果确定合成后的样品中有 $\mathrm{CaZrO}_{3}$ 基固溶体和微量的 $\mathrm{MgO}$ 存在. 为了 明确 $\mathrm{CaZr}_{1-x} \mathrm{Mg}_{x} \mathrm{O}_{3-\alpha}$ 的电化学性能, 采用交流阻抗法在1073 1473 K, 富氧气氛 $\left(\mathrm{Ar} / \mathrm{O}_{2} / \mathrm{D}_{2} \mathrm{O}\right) /\left(\mathrm{Ar} / \mathrm{O}_{2} / \mathrm{H}_{2} \mathrm{O}\right)$ 和富氢气 氛 $\left(\mathrm{Ar} / \mathrm{H}_{2} / \mathrm{H}_{2} \mathrm{O}\right) /\left(\mathrm{Ar} / \mathrm{D}_{2} / \mathrm{D}_{2} \mathrm{O}\right)$ 下测量了固体电解质的电导率及其同位素效应与气氛依赖性. 通过检测电导率的 $\mathrm{H} / \mathrm{D}$ 同位素效应，确定了固体电解质的质子导电优势区域. 结果显示在富氢气氛下，测定的1073 1473 K温度范围内 有明显的 $\mathrm{H} / \mathrm{D}$ 同位素效应, 表明质子是主要的载流子. 在富氧气氛下, 1073 1273 K温度范围内, 质子也是主要的 载流子. 该材料有可能作为氢传感器的固体电解质.
\end{abstract}

关键词稀土, 质子, 电导率, 同位素效应, 质子导体

目前，离子器件和电子器件一样得到了巨大的 发展, 尤其是在熔融金属等冶炼领域得到了广泛的 应用, 例如金属液定氢传感器. 铜和铜合金具有良好 的综合性能, 在国民经济和国防中有一系列的重要 用途，而冶炼过程中，当熔铜和铜合金凝固时，氢的 析出会使铸件和板材中形成气孔、白点等缺陷, 显著 降低产品的气密性、强度、塑性、冲击韧性及断裂韧 性, 进而对薄板材料、动力车及航空部件的性能产生 严重影响, 因此有必要对铜液中的氢含量进行监测 及控制. 目前, 固体电解质, 尤其是缺陷结构型质子 导电体氧化物材料已经被广泛应用于铝合金熔体中 氢气浓度的测量. 随着固体电解质理论及应用的不 断发展 ${ }^{[1 ~ 5]}$, 开发具有更高测量精度、更长工作时间、 更低廉价格且适用于工业环境的铜液定氢电化学传 感器、进而促进冶金和材料生产的发展已经成为研究 机构以及工厂的研究热点. 对金属熔液中的氢含量 进行准确、简便的测量在冶金及材料生产过程中具有
十分重要的意义, 但现有的氢传感器存在着连续工 作时间短、测量精度差和价格昂贵等一系列问题, 研 究较为广泛的氢传感器电解质 $\left(\mathrm{In}\right.$ 掺杂 $\mathrm{CaZrO}_{3}$ ) 在低 温领域有较好的化学稳定性, 且在铝液定氢传感器 中获得了应用，但在 $1473 \mathrm{~K}$ 以上温度下化学稳定性 差, 影响掺杂效果 ${ }^{[6 ~ 13]}$, 导致金属液定氢传感器的测

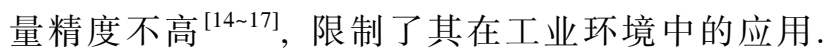
为此本文开展了对 $\mathrm{CaZrO}_{3}$ 掺杂 $\mathrm{Mg}$ 的研究, 制备了不 同掺杂量的样品, 并采用交流阻抗谱法测定其在不 同温度下的电导率; 分析了质子导电优势区域，电导 率与掺杂量的关系, 由实验总结出电导率与掺杂量 及温度的相关关系, 得到该材料的最佳掺杂量, 为该 材料的进一步扩大应用奠定基础. 本文在阐明其质 子电导优势区域及化学稳定性的基础上探讨其在金 属熔融传感器电解质上应用的可能性. 此类质子导 体材料比氧化铟系列制作成本较低, 具有重要的应 用价值. 


\section{1 实验}

(i) 固体电解质制备. 制备试样的出发原料为 $\mathrm{CaCO}_{3}$ (分析纯)、 $\mathrm{ZrO}_{2}$ (分析纯) 和 $\mathrm{MgO}$ (分析纯), 按目 标产物 $\mathrm{CaZr}_{1-x} \mathrm{Mg}_{x} \mathrm{O}_{3-\alpha}(x=0,0.001,0.005,0.02)$ 的化学 计量比称量原料, 采用固相合成法制备质子导体固 体电解质. 以无水乙醇为介质, 置于砂磨机中砂磨 $2 \mathrm{~h}$, 转速为 $2500 \mathrm{r} / \mathrm{min}$. 将混合、砂磨、干燥后的粉 体在 $10 \mathrm{MPa}$ 压力下用小型双向液压机进行压片. 成 型的试样在空气气氛下 $1673 \mathrm{~K}$ 恒温煅烧 $10 \mathrm{~h}$, 将炦烧 后的样品, 用砂磨机研磨 $2 \mathrm{~h}$, 得到自制粉体, 采用 Verneuil法制备试样. 使用冷等静压在 $200 \mathrm{MPa}$ 的压 力下将合成后的粉料压制成型后, 在空气中 $1873 \mathrm{~K}$ 下烧结 $16 \mathrm{~h}$ 进行二次烧结, 提高了样品的强度及致密 度. 采用Philips PW 3040/60型X射线衍射仪(XRD, $\mathrm{Cu} \mathrm{K} \alpha$, 单晶硅做内标) 对煅烧后的粉料进行 XRD物 相分析, 确认合成了 $\mathrm{CaZr}_{1-x} \mathrm{Mg}_{x} \mathrm{O}_{3-\alpha}$ 粉体. 得到的样 品为直径 $6.3 \mathrm{~mm}$, 厚度 $0.72 \mathrm{~mm}$ 的圆片. 在本文中, 采用致密度 $96 \%$ 或更高的样品进行电导率及 $\mathrm{H} / \mathrm{D}$ 同位 素测试.

(ii) 样品测试. 在固相合成制备的试样 $\mathrm{CaZr}_{1-x^{-}}$ $\mathrm{Mg}_{x} \mathrm{O}_{3-\alpha}(x=0,0.001,0.005,0.02)$ 的 2 个面上涂1层铂浆, $1073 \mathrm{~K}$ 下炦烧 $4 \mathrm{~h}$, 连接铂金丝及铂金电极组成电池. 氛围气体是 $\left(\mathrm{Ar} / \mathrm{O}_{2} / \mathrm{D}_{2} \mathrm{O}\right) /\left(\mathrm{Ar} / \mathrm{O}_{2} / \mathrm{H}_{2} \mathrm{O}\right),\left(\mathrm{Ar} / \mathrm{H}_{2} / \mathrm{H}_{2} \mathrm{O}\right) /$ $\left(\mathrm{Ar} / \mathrm{D}_{2} / \mathrm{D}_{2} \mathrm{O}\right)$, 混气装置控制炉内气氛(恒温带长度大 于 $80 \mathrm{~mm}$, 精度为 $\pm 1 \mathrm{~K}$ ), 把混合好的气体通过水蒸 气饱和装置保持一定的水分压. 电化学测量采用 NF 制造的 2345LCZ阻抗仪 (测量频率: 40 100 Hz) 和 HIOKI制造的3532-80化学阻抗仪(测量频率: $4 \mathrm{~Hz} 1$ $\mathrm{MHz}$, 电化学接口3532-80), 试样的质子导体电导率 及H/D同位素效应在1073 1673 K, 40 100 kHz频率 范围下进行测量, 实验装置如图1所示.

\section{2 结果与分析}

\section{$2.1 X R D$ 物相分析}

出发原料 $\mathrm{CaCO}_{3}, \mathrm{ZrO}_{2}$ 和 $\mathrm{MgO}$ 混合, 经 $1673 \mathrm{~K}$ 恒 温 $10 \mathrm{~h}$ 煅烧后得到的 $\mathrm{CaZr}_{1-x} \mathrm{Mg}_{x} \mathrm{O}_{3-\alpha}(x=0,0.005$, $0.10,0.15)$ 粉体的XRD图谱如图2所示. 煅烧粉体的 衍射峰位置和相对强度与 $\mathrm{CaZrO}_{3}$ 标准峰基本一致, 且未检测到原始氧化物, 说明混合粉料经 $1673 \mathrm{~K}$ 恒 温 $10 \mathrm{~h}$ 煅烧已经形成预期的钙钛矿型 $\mathrm{CaZrO}_{3}$ 基固溶 体. 掺杂后的主峰相对于标准峰发生微弱偏移, 这是

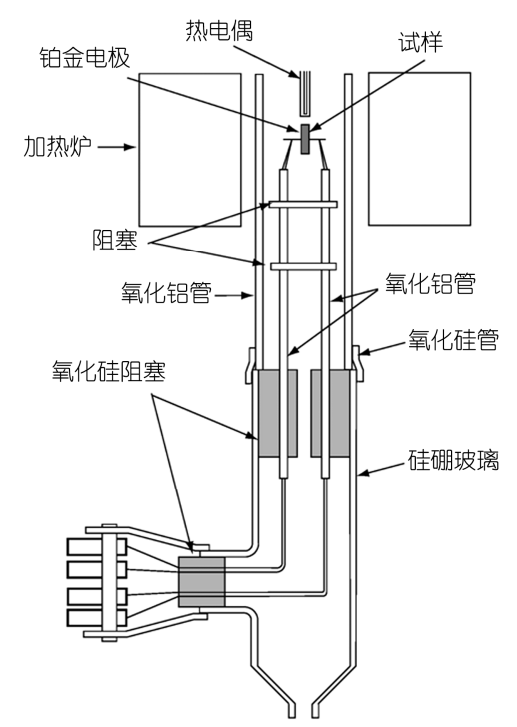

图 1 电导率测试装置

Figure 1 Schematic view of experimental apparatus

由于 $\mathrm{Mg}^{2+}$ 的半径为 $0.078 \mathrm{~nm}, \mathrm{Zr}^{4+}$ 的半径为 $0.072 \mathrm{~nm}$, 较大离子半径的 $\mathrm{Mg}^{2+}$ 掺杂替代 $\mathrm{Zr}^{4+}$ 产生晶格畸变, 致 使衍射峰位置发生微小偏移. 而当掺杂量 $x=0.01$ 以上 时, 样品的XRD图谱中出现了微量第二相 $\mathrm{MgO}$. 因 此, $\mathrm{Mg}$ 掺杂 $\mathrm{CaZrO}_{3}$ 的固溶极限为 $0.1 \%$ (摩尔百分比).

\subsection{H/D同位素效应}

根据同位素效应原理, 当电解质中优势的电荷 载体为质子的情况下 $\mathrm{H} / \mathrm{D}$ 电导率相差 1.37 倍, 是由于 电荷载体从质子置换成重氢时质量变化而导致. 如 图3所示, 在923 K下, 对 $\mathrm{CaZr}_{0.995} \mathrm{Mg}_{0.005} \mathrm{O}_{3-\alpha}$ 固体电 解质进行了同位素测量. 当测试环境气氛由 $\left(\mathrm{Ar} / \mathrm{D}_{2} /\right.$ $\left.\mathrm{D}_{2} \mathrm{O}\right)$ 变为 $\left(\mathrm{Ar} / \mathrm{H}_{2} / \mathrm{H}_{2} \mathrm{O}\right)$ 时, 电解质的阻抗变小, 达到

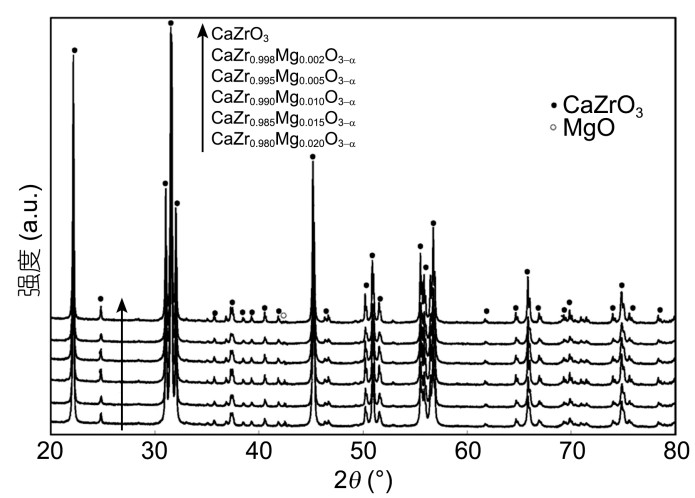

图 $2 \mathrm{CaZr}_{1-x} \mathrm{Mg}_{x} \mathrm{O}_{3-\alpha}$ 的XRD图谱

Figure 2 XRD pattern for $\mathrm{CaZr}_{1-x} \mathrm{Mg}_{x} \mathrm{O}_{3-\alpha}$ 


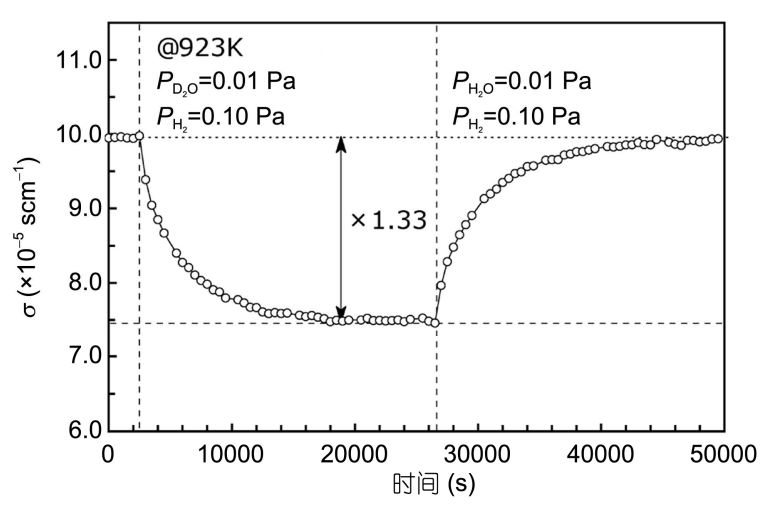

图 $3 \mathrm{CaZr}_{0.995} \mathrm{Mg}_{0.005} \mathrm{O}_{3-\alpha}$ 的 $\mathrm{H} / \mathrm{D}$ 同位素效应测试结果

Figure $3 \mathrm{H} / \mathrm{D}$ isotope effect on the electrical conductivity for $\mathrm{CaZr}_{0.995} \mathrm{Mg}_{0.005} \mathrm{O}_{3-\alpha}$

平衡以后的电导率相差 1.33 倍, 这与 $\mathrm{Al}$ 掺杂 $\mathrm{CaZrO}_{3}$ 系统检测到的结果相似 ${ }^{[6]}$. H/D同位素效应检测结果 表明, $923 \mathrm{~K}$ 的低温区域, 质子是优势电荷载体. 综合 电导率H/D同位素分析结果, 制备的固体电解质在 973 K左右的温度区域优势的电荷载体是质子. 这初 步确定 $\mathrm{CaZr}_{0.995} \mathrm{Mg}_{0.005} \mathrm{O}_{3-\alpha}$ 具有质子导电性, 关于更 高温度区域的质子电导特性在温度与电导率测试结 果中进行讨论.

\section{3 电导率对温度的依赖性}

在一般的固体电解质质子导体的质子传输原理 中, 试样的电阻分为晶粒阻抗、晶界阻抗及两面烧结 的测量电极阻抗. 样品的电阻 $R$ 可以根据交流阻抗谱 得出, 在不同温度下试样的电导率可以利用式(1)进 行计算. 式中 $\sigma$ 是样品电导率 $(\mathrm{S} / \mathrm{cm}), R$ 是试样电阻 $(\Omega), L$ 为试样厚度 $(\mathrm{cm}), S$ 是试样截面积 $\left(\mathrm{cm}^{2}\right)$.

$$
\sigma=L / R S \text {. }
$$

在含水氩气气氛中, 不同温度下分别测定了 $\mathrm{CaZr}_{1-x} \mathrm{Mg}_{x} \mathrm{O}_{3-\alpha}(x=0.001,0.015,0.02)$ 的交流阻抗谱, 结果示于图 $4, R$ 和 $-X$ 分别指实部与虚部. 结果表明, 随着温度的升高, $\mathrm{CaZr}_{1-x} \mathrm{Mg}_{x} \mathrm{O}_{3-\alpha}$ 的阻抗逐渐减小, 因为随着环境温度的升高在固体电解质中的质子迁 移速度加快.

在不同气氛下 $\left(\mathrm{Ar} / \mathrm{O}_{2} / \mathrm{D}_{2} \mathrm{O}\right) /\left(\mathrm{Ar} / \mathrm{O}_{2} / \mathrm{H}_{2} \mathrm{O}\right),\left(\mathrm{Ar} / \mathrm{H}_{2} /\right.$ $\left.\mathrm{H}_{2} \mathrm{O}\right) /\left(\mathrm{Ar} / \mathrm{D}_{2} / \mathrm{D}_{2} \mathrm{O}\right)$ 得到不同掺杂量 $\mathrm{CaZr}_{1-x} \mathrm{Mg}_{x} \mathrm{O}_{3-\alpha}$ 的 电导率与温度的关系图, 如图5所示. 根据不同温度 下的实验数据及式(1)的计算结果, 用 $\ln (\sigma T)$ 对 $1000 / T$ 进行绘图, 结果显示 $\ln (\sigma T)-1000 / T$ 呈近似线性关系, 此结果符合Arrhenius公式(式(2)). 式中, $E_{\mathrm{a}}$ 为电导激

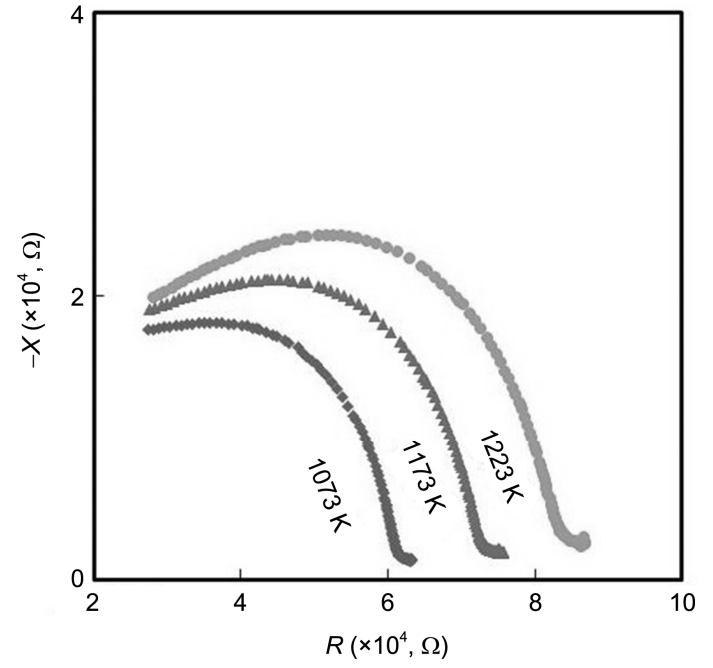

图 $4 \mathrm{CaZr}_{0.995} \mathrm{Mg}_{0.005} \mathrm{O}_{3-\alpha}$ 不同温度下的电阻变化

Figure 4 Resistance change of $\mathrm{CaZr}_{0.995} \mathrm{Mg}_{0.005} \mathrm{O}_{3-\alpha}$ undet different temperatures

活能 $(\mathrm{eV})$, 常数 $A$ 与电解质本性、结构等有关, $k$ 为 Bolzman常数, $T$ 表示温度 $(\mathrm{K})$.

$$
\ln (\sigma T)=\ln A-E_{\mathrm{a}} / k T .
$$

根据Arrhenius公式及实验结果，不同温度及不 同掺杂量时 $\mathrm{CaZr}_{1-x} \mathrm{Mg}_{x} \mathrm{O}_{3-\alpha}$ 的电导率与温度的 Arrhenius曲线结果如图5所示. 在富氧气氛中, 低温 (1473 K或更低)时有H/D同位素效应，因此，在这些 条件下，质子似乎成为主要的载流子. 相反，在高温 (1473 K或更高)没有 $\mathrm{H} / \mathrm{D}$ 同位素效应，所以在更高的 温度区内主要载流子不是质子. 另一方面, 在富氢气 氛下，几乎整个测量温度范围内均有H/D同位素效 应，因此，在这些条件下，质子导电似乎是主要的导 电种类. 电导率的这些气氛依赖性与 $\mathrm{Al}$ 掺杂 $\mathrm{CaZrO}_{3}$ 系统检测到的结果相似. 在 2 种气氛中, $\mathrm{CaZr}_{0.9} \mathrm{In}_{0.1} \mathrm{O}_{3}$ 的电导率均比 $\mathrm{CaZr}_{0.99} \mathrm{Mg}_{0.01} \mathrm{O}_{3-\alpha}$ 的高 ${ }^{[7,8]}$. 受主掺杂的 增加通常会导致载流子如孔穴、质子和氧离子空位的 浓度的升高. 因此，这种增加趋势是合理的．在2种 气氛中, $\mathrm{CaZr}_{0.99} \mathrm{Mg}_{0.01} \mathrm{O}_{3-\alpha}$ 受主掺杂 $\mathrm{X}$ 的增加通常会 导致载流子如孔穴、质子和氧离子空位的浓度的升 高. 实验结果表明, $\mathrm{M}$ 掺杂量对氧化铝基陶瓷质子导 电性能有明显的影响，但掺杂量并非越多越好：(1) 过多的氧缺陷，往往会发生质子捕获形成稳定的结 构，对质子传输不利；(2) 过多的掺杂导致生成第二 相，阻碍质子的迁移速度. 因此，严格控制 $\mathrm{M}$ 掺杂量 的基础上可以获得高导电率及质子迁移率的固体质 

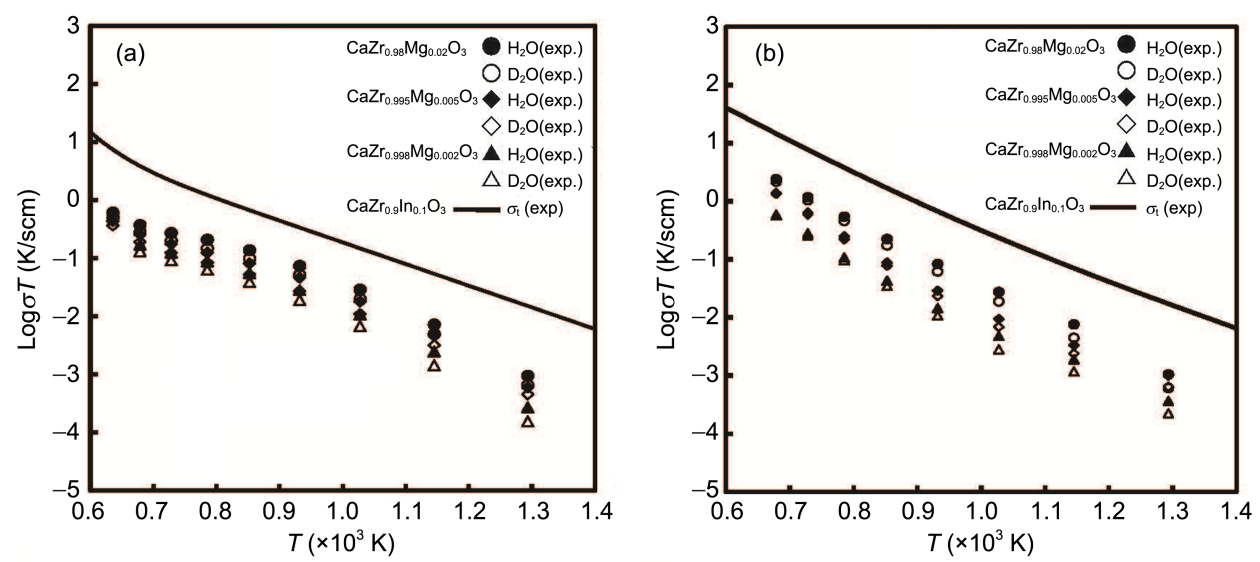

图 5 氢气(a)和氧气(b)气氛下电导率随掺杂量及温度变化的Arrhenius曲线

Figure 5 Arrhenius plots of the electrical conductivity under hydrogen (a) and oxygen-rich (b) atmospheric conditions

子导电材料.

\section{4 电导率的气氛依赖性}

固体电解质质子导体材料的导电率与外围气氛 的关联, 使用电化学工作站测量, 阐明了稀土离子掺 杂量、温度、气体分压、气体流速、气氛对固体电 解质质子导电率的影响. 固体电解质的质子导电性 $\left(\sigma_{\mathrm{H}+}\right)$ 与质子电荷数 $(\mathrm{e})$ 、质子浓度 $\left(C_{\mathrm{H}+}\right)$ 、质子迁移率 $\left(\mu_{\mathrm{H}+}\right)$ 、质子扩散率 $\left(D_{\mathrm{H}+}\right)$ 及与其邻近的晶格氧离子的 结合能有关. 通过实验和模拟可以揭示影响质子传 输的各种因素之间的关系. 关于锆酸钙质子导体的 质子导电机理虽有许多探索与研究, 但并未形成一 种成熟的理论. 导电机理方面的研究可以用缺陷理 论来解释, 由于低价元素 $\mathrm{M}$ 的掺杂, 占据 $\mathrm{Al}$ 位后产
生负电荷, 根据电中性原理, 同时必然产生带正电 荷的氧空位或者电子空穴, 从而在含氢或水蒸气气 氛中产生质子.

当 $\mathrm{H}_{2} \mathrm{O}$ 活度为 0.01 时, 在富氧气氛下测得的电导 率作为氧活度的函数 $\log -\log$ 图如图6(a)所示. 从图中 可以看出, 在较高温度下, 电导率成比例增加至近似 氧活度的 $1 / 4$. 在低的温度范围, 电导率与氧活度的 关系趋势不再明显. 根据电导率与温度依赖结果可 测得的 H/D同位素效应, 质子是主要载流子. 当氧活 度设定在 0.01 时, 电导率与水蒸气关系的函数 $\log -\log$ 图如图6(b)所示. 从图中可以看出, 在较高温度下, 电导率保持恒定, 与水蒸气活度无关, 反之在较低温 度范围内, 即质子成为主要的载流子, 电导率呈现出 成比例增长, 达到蒸气活度的 $1 / 2$.
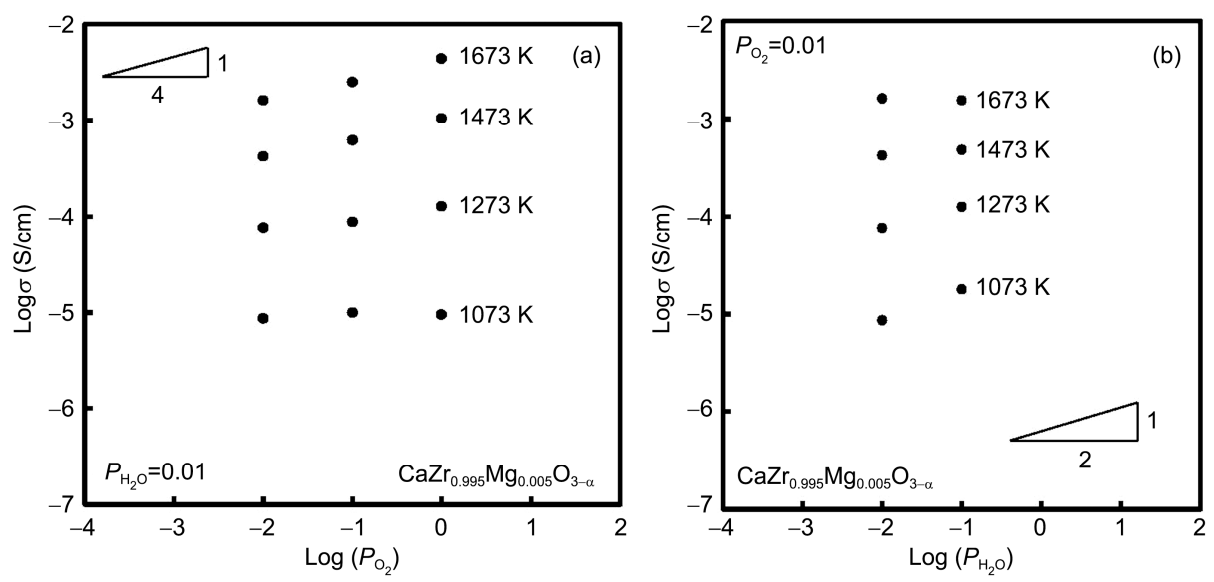

图 6 富氧气氛下的电导率与环境气氛的关系. (a) 氧气; (b) 水蒸气

Figure 6 The oxygen (a) and water vapor (b) activity dependence of electrical conductivity in an oxygen-rich atmosphere 


\section{3 结论}

根据粉末衍射实验结果, $\mathrm{Mg}$ 掺杂 $\mathrm{CaZrO}_{3}$ 中 $\mathrm{Mg}$ 的 固溶极限为 $0.2 \mathrm{~mol}$. $\mathrm{CaZr}_{1-x} \mathrm{Mg}_{x} \mathrm{O}_{3-\alpha}$ 同位素效应及 电导率的测量结果显示, 在1073 1473 K温度范围 内、富氧气氛下, 质子是主要的载流子. 电导率随着
温度的升高而增大，且随着水蒸气分压的增大呈现 逐渐增大的趋势.

这些结果表明, $\mathrm{CaZrO}_{3}$ 中掺杂 $\mathrm{Mg}$ 质子导体固体 电解质在富氢气氛下, 有较纯的质子电导率, 是一种 替换现在使用的金属液氢传感器探针 $\mathrm{In}$ 掺杂 $\mathrm{CaZrO}_{3}$ 的备选材料.

\section{参考文献}

1 Medvedev D, Lyagaeva J, Plaksin S, et al. Sulfur and carbon tolerance of $\mathrm{BaCeO}_{3}-\mathrm{BaZrO}_{3}$ proton-conducting materials. J Power Sources, 2015, 273: 716-723

2 Zhao R R, Hung I M, Li Y T, et al. Synthesis and properties of Co-doped $\mathrm{LiFePO}_{4}$ as cathode material via a hydrothermal route for lithium-ionbatteries. J Alloy Compd, 2012, 513: 282-288

3 Chen J H, Shen M Q, Wang X Q, et al. Catalytic performance of $\mathrm{NO}$ oxidation over $\mathrm{LaMeO}_{3}(\mathrm{Me}=\mathrm{Mn}, \mathrm{Fe}$, Co) perovskite prepared by the sol-gel method. Catal Commun, 2013, 37: 105-108

4 Wang S W, Zhao F, Zhang L L, et al. Stability and electrical property of $\mathrm{Ba}_{1-x} \mathrm{Sr}_{x} \mathrm{Ce}_{0.8} \mathrm{Y}_{0.2} \mathrm{O}_{3-\delta}$ high temperature proton conductor. J Alloy Compd, 2010, 506: 263-267

5 Yuan W, Xiao C, Li L. Hydrogen permeationand chemical stability of In-doped $\mathrm{SrCe}_{0.95} \mathrm{Tm}_{0.05} \mathrm{O}_{3-\delta}$ membranes. J Alloy Compd, 2014, 616: $142-147$

6 Waser R. Diffusion of hydrogen defects in $\mathrm{BaTiO}_{3}$ ceramics and $\mathrm{SrTiO}_{3}$ single crystals. Bunsenges B Phys Chem, 1986, 90: 1223

7 Kreuer K D. On the development of proton conducting materials for technological applications. Solid State Ion, 1997, 97: 1-15

8 Müller J, Kreuer K D, Maier J, et al. A conductivity and thermal gravimetric analysis of a Y-doped $\mathrm{SrZrO}_{3}$ single crystal. Solid State Ion, 1997, 97: 421-427

9 Scholten M J, Schoonman J, van Miltenburg J C. Synthesis of strontium and barium cerate and their reaction with carbon dioxide. Solid State Ion, 1993, 61: 83-91

10 Yajima T, Kazeoka H, Yogo T. Proton conduction in sintered oxides based on $\mathrm{CaZrO}_{3}$. Solid State Ion, 1991, 47: 271-275

11 Cano C, Osendi M I, Belmonte M, et al. Effect of the type of flame on the microstructure of $\mathrm{CaZrO}_{3}$ combustion flame sprayed coatings. Surface Coat Technol, 2006, 201: 3307-3313

12 Shimura T, Esaka K, Matsumoto H. Protonic conduction in Rh-doped $\mathrm{AZrO}_{3}$ (A=Ba, Sr and Ca). Solid State Ion, 2012, 149: 237-246

13 Zheng W, Pang W, Meng G. Hydrothermal synthesis of $\mathrm{SrZrO}_{3-\alpha}(\mathrm{M}=\mathrm{Al}$, Ga, In, $x \leqslant 0.20)$ series oxides. Solid State Ion, 1998, 108: 37-41

14 Bao J, Ohno H, Kurita N, et al. Proton conduction in Al-doped $\mathrm{CaZrO}_{3}$. Electrochim Acta, 2011, 56: 1062-1068

15 Le J, van Rij L N, van Landschoot R C, et al. A wet-chemical method for the synthesis of In-doped $\mathrm{CaZrO}_{3}$ ceramic powders. J Eur Ceram Soc, 1999, 19: 2589-2591

16 Han J D, Wen Z Y, Zhang J C, et al. Synthesis and characterization of proton conductive $\mathrm{CaZr}_{0.90} \mathrm{In}_{0.10} \mathrm{O}_{3-\delta}$ by a citric acid complexation method. Fusion Eng Des, 2010, 85: 2100-2104

17 Ahmed I, Eriksson S G, Ahlberg E, et al. Synthesis and structural characterization of perovskite type proton conducting $\mathrm{BaZr}_{1-x} \mathrm{In}_{x} \mathrm{O}_{3-\delta}$ $(0.0 \leqslant x \leqslant 0.75)$. Solid State Ion, 2015, 177: 1395-1403 


\title{
Properties of electric conductivity of $\mathrm{CaZr}_{1-x} \mathrm{Mg}_{x} \mathrm{O}_{3-\alpha}$ in sensors electrolyte
}

\author{
BAO JinXiao, WANG WeiWei \& GUO WenRong \\ School of Material and Metallurgy, Inner Mongolia University of Science and Technology, Baotou 014010, China
}

For measurement of high-temperature combustion gases such as $\mathrm{NO}_{x}, \mathrm{CO}, \mathrm{H}_{2}$, etc., mixed potential gas sensors utilized solid-electrolyte yttria-stabilized zirconia (YSZ) and metal-oxide sensing electrodes have been known as very good and promising selections. One of the most interesting sensing electrodes material is the perovskite-type oxide $\mathrm{ABO}_{3}$ ( $\mathrm{A}$ cation of rare earth element, $\mathrm{B}$ cation of $3 \mathrm{~d}$ transition metal and $\mathrm{O}$ anion of oxygen) due to having more exciting gas-catalytic characteristics, stability and robustness in high temperature environments. Proton or oxide-ion conducting solid oxide electrolytes are useful for various electrochemical devices. They have been also proposed for membrane reactors, e.g., in particular, solid oxide fuel cells (SOFCs) are important as alternative electrical power generating systems with high energy-conversion efficiency. Recently, several perovskite-type proton conducting oxides, such as $\mathrm{CaZrO}_{3}$ and $\mathrm{BaCeO}_{3}$ based materials, have been suggested as alternate electrolyte materials for the intermediate temperature fuel cells owing to their higher ionic conductivities and lower the activation energy as compared to the conventional oxygen-ion conducting electrolytes. In this class of compounds, yttrium-doped $\mathrm{CaZrO}_{3}(\mathrm{CZY})$ and $\mathrm{BaCeO}_{3}(\mathrm{BCY})$ have exhibited considerable proton conductivity with low migration energy in the intermediate temperature range. Nevertheless, materials for proton conducting membranes are still not sufficiently developed, and therefore extensive investigations of proton absorption and migration mechanisms, as well as further application tests are needed. As a solid electrolyte has the properties of both solid and ion conductor, it has been generally utilized conveniently for chemical sensors, fuel cells, coulometric measurement devices, etc.

In this study, $\mathrm{CaZrO}_{3-\alpha}$ based solid electrolyte was prepared by a solid-state reaction method, starting materials are the 99.99\% purity $\mathrm{CaCO}_{3}, \mathrm{ZrO}_{2}$ and $\mathrm{MgO}$ powders. The mechanochemical treatment was carried out in a nitrogen atmosphere using a planetary ball mill with an agate pot and ball. The rotation speeds of the milling pot and table were maintained at $720 \mathrm{r} / \mathrm{min}$ with a constant rotation ratio of $1: 1: 1$ for $1 \mathrm{~h}$. The volume of the pot was $45 \mathrm{~mL}$ and 10 balls of $10 \mathrm{~mm}$ diameter were used for the mechanochemical treatment. The powders were mixed in a ball mill and cold-isostatic ally pressed into pellets at $200 \mathrm{MPa}$, and finally sintered at $1600 \mathrm{C}$ for $10 \mathrm{~h}$ in air. The pellets were ground again and sieved into a uniform-sized powder. The powder was pressed into pellets using 10-mm diameter dies at a pressure of approximately $1.5 \mathrm{ton} / \mathrm{cm}^{2}$, and then statically pressed at a pressure of approximately 2 ton/ $\mathrm{cm}^{2}$. Finally, the pellets were calcined in alumina crucibles at the optimum temperature $1873 \mathrm{~K}$ for $16 \mathrm{~h}$ in air to obtain $\mathrm{CaZrO}_{3-\alpha}$ based solid electrolyte polycrystalline ceramics. To clarify the high temperature electrochemical properties of $\mathrm{Mg}$-doped $\mathrm{CaZrO}_{3}$, the electrical conductivity of the poly-crystalline specimen was measured in various kinds of hydrogen and oxygencontaining atmospheres by employing the two terminal AC method. The H/D isotope effect of the electrical conductivity was examined in detail in order to specify the conditions in which the proton conduction was dominant. In the temperature range from 1073 to $1473 \mathrm{~K}$, it was found that protons were the dominant charge carrier both in hydrogen-rich and oxygen-rich atmospheres. The material is likely to serve as a solid electrolyte for hydrogen sensor.

rare earth, proton, conductivity, isotope effect, hydrogen sensor

doi: 10.1360/N972015-00994 